\section{Performance of transgenic and conventional soybean plants subjected to bioassay for detection of glyphosate tolerant seeds}

\section{Welison Andrade Pereira ${ }^{1 *}$, Alisson Santos Lopes da Silva², Danúbia Aparecida Costa Nobre ${ }^{3}$, Guilherme de Sousa Paula ${ }^{2}$ and Felipe Lopes da Silva²}

\begin{abstract}
The adoption of genetically modified soybean cultivars is increasing annually around the world, which indicates the excellence of these genotypes. For soybean breeding, the use of such cultivars in a backcross program relies on the ability to detect the transgenic trait. The germination test in a moistened substrate with glyphosate is effective and of low cost, however, wonders whether this is a non-destructive method to check cultivars. The objective of this study was to apply a bioassay for detection of herbicide-tolerant seeds and to evaluate the vegetative and productive development of the plants. It was observed that both glyphosate-tolerant and glyphosate-sensitive plants were affected in the initial stages of development in accordance with the herbicide application rate. However, whereas tolerant plants fully recover both in vegetative growth and production during the cycle, sensitive plants recover partially, producing smaller plants with lower yield as a consequence of the herbicide application rate.
\end{abstract}

Key words: Glycine max, GMO detection, germination, viability, productivity.

\section{INTRODUCTION}

It is plausible to consider that the yield of a crop is the result of crop management practices, plant breeding, favorable soil and weather conditions, and the interactions among these three factors. In this respect, genetically modified (GM) soybean tolerant to glyphosate is an example of breeding that intersects with improvement in crop practices.

Among these crop practices, weed control contributes to production stability because it can avoid the serious damage caused by invasive plants (Pittelkow et al. 2009). Weeds compete with the crop for light, nutrients, and water, harm the crop, and can serve as hosts to pests and diseases, thus reducing yield by $46 \%$ (Nepomuceno et al. 2007).

Important in weed control are EPSPS inhibitor herbicides, with systemic, total action, broad spectrum control of mono- and dicotyledons, both annual and perennial. They are taken up into the shoots and are easily assimilated by the entire plant. These herbicides are applied in weed post-emergence and crop pre-emergence; they are quickly adsorbed by the soil and have low toxicity to all those who do not have the EPSPS enzyme (Kruse et al. 2000).

The limiting factor for application of these herbicides to soybean [G/ycine
Crop Breeding and Applied Biotechnology 18: 39-46, 2018 Brazilian Society of Plant Breeding. Printed in Brazil http://dx.doi.org/10.1590/198470332018v18n1a6

\author{
*Corresponding author: \\ E-mail: welison.pereira@dbi.ufla.br \\ Received: 23 November 2016 \\ Accepted: 01 July 2017
}

\footnotetext{
${ }^{1}$ Universidade Federal de Lavras, Departamento de Biologia, 37.200-000, Lavras, MG, Brazil

${ }^{2}$ Universidade Federal de Viçosa, Departamento de Fitotecnia, Avenida PH Rolfs s/n, 36.570-900, Viçosa, MG, Brazil

${ }^{3}$ Instituto Federal do Norte de Minas Gerais, Ciências Agrárias, 38.680-000, Arinos, MG,
} Brazil 
max (L.) Merrill] was the sensitivity of cultivars to their active ingredient. However, with the advent of the glyphosatetolerant lineage (Padgette et al. 1995), this obstacle was resolved, and this biotech event triggered the largest number of approvals ( 52 in over 26 countries) of all the transgenic events currently available. The glyphosate-tolerant (GT) soybean, the GTS-40-3-2 event, synthesizes the CP4 EPSPS enzyme (5-enolpyruvyl-shikimate-3-phosphate-synthase), a version insensitive to the herbicide due to one substitution (Gly-100-Ala) in its active site (Funke et al. 2006).

In general, the development of GM varieties has led to significant advances in agriculture, such as a $22 \%$ increase in yield and 68\% increase in profits for the producer (Klümper and Qaim 2014), encouraging the adoption and establishment of GM crops in over 181 million hectares spread across 28 countries (James 2014).

Given the dynamics of the aims of plant breeding, it is natural that transgenic lines have many interesting characteristics for a breeding program. Herbicide-tolerant cultivars behave in a similar way and may be used for genetic improvement (Matsuo et al. 2009). From hybridizations, segregating populations can be conducted in the search for superior genotypes, which may or may not include the transgenic trait. Regardless of the target, scanning the population for the presence of the CP4 EPSPS gene may be required, as in fact was performed experimentally by De Vries and Fehr (2011).

There are numerous possibilities for detecting the transgene (Conceição et al. 2006, Fraiture et al. 2015). However, in spite of this diversity, we must consider the limitations in terms of equipment and the costs of adoption of molecular methods for analysis of large amounts of material. The germination test has proven to be relatively cheap, practical, and reliable (Pereira et al. 2009a) and its efficiency has been experimentally confirmed both to indicate the presence of individuals tolerant to the herbicide in the sample and to quantify the mixture (Miranda et al. 2006, Pereira et al. 2009a).

In this context, evaluating the performance of soybean cultivars after their seeds have germinated in a moistened substrate with herbicide solution provides information regarding the effect of this test on the development of cultivars tolerant and sensitive to the herbicide. It may be that seedlings of sensitive cultivars can be transferred to ground where there is no herbicide anymore, and the units of EPSPS not aggregated to glyphosate, or those dissociated from it, would be able to allow the recovery of these plants and the continuity of the life cycle.

Thus, the objective of this study was to analyze the viability, development, and production performance of the seedlings that germinated under the conditions of this test.

\section{MATERIAL AND METHODS}

Six soybean [Glycine max (L.) Merrill] cultivars were used - five herbicide-tolerant cultivars (UFVS Agua Marinha RR, UFVS Berilo RR, UFVS Citrino RR, UFVS Opala RR, and UFVS Turqueza RR) and one herbicide-sensitive cultivar (UFV-16).

The germination test recommended by the Rules for Seed Analysis (Brasil 2009) was adapted for this study. To moisten the germination paper in the control treatment, a water volume in the proportion of 2.5 times the weight of the dry substrate, obtained by an analytical balance, was used. In the other treatments, the same volume of solutions at concentrations of $0.03,0.06$, and $0.12 \%$ of the acid equivalent of glyphosate were used (Pereira et al. 2009a). The test was conducted with 4 replicates of 50 seeds, which were placed on rolls of paper towel, moistened with distilled water, and placed in a germinator at $25^{\circ} \mathrm{C}$ (Brazil 2009). The percentage of normal seedlings was obtained at 5 days for the first count and 8 days for the final germination count.

The seedling length test was conducted by the procedure and under conditions similar to the germination test above (Pereira et al. 2009a), with some adaptations (Pereira et al. 2009b). The experiment consisted of 8 replicates of 10 seeds, distributed in the upper third of the paper towels. Rolls made from these papers were kept at the controlled temperature of $25^{\circ} \mathrm{C}$ in BOD for 7 days, at which time the hypocotyl, radicle, and seedlings were measured with a millimeter ruler.

For the study of plant performance in a greenhouse, a new germination test in moistened substrate with glyphosate was established, conducted as previously described. At 7 days, 10 typical seedlings from each plot were transplanted into $2.5 \mathrm{~L}$ capacity pots containing a mixture of soil, sand, and manure in the proportion of 3:1:1, and this soil was incubated in containers with dolomitic limestone (PRNT 96\%) for soil correction 30 days before transplanting the seedlings.

During the cycle (November/2014 to May/2015), the following measures were taken: height of the plant and first pod height (millimeter ruler), diameter of the hypocotyls (digital caliper rule), dry weight of stems and pods (analytic 
balance with $0.001 \mathrm{~g}$ resolution), number of branches, pods, seeds, and seeds per pod (manual count), and yield per plant (total weight of grains obtained on an analytical balance with $0.001 \mathrm{~g}$ resolution, corrected for water content of 13\%), according to Albrecht et al. (2014).

Each experiment was carried out in a completely randomized design in a factorial arrangement composed of 6 cultivars $x 4$ application rates of herbicide. The purpose of the current study was not to compare cultivars with each other, but to check the effect of herbicide application rates on each particular genotype. The factorial arrangement allowed us to observe the existence of interaction between the factors, indicating the possibility of additional inferences and future studies.

The assumptions for analysis of variance were verified. Thus, we proceeded to analysis of variance and the Scott and Knott test at 5\% probability using the statistical program GENES (Cruz 2013). The graphs illustrate comparisons within each genotype and not between them, which were omitted in these results. The germination data were transformed into $\operatorname{Arcsin} \sqrt{x / 100}$, but in the Table, the data in percentage were shown for better visualization and understanding of the results.

\section{RESULTS AND DISCUSSION}

Regarding the ANOVA assumptions, the data showed homogeneity of variance by Bartlett's test and normal distribution by Lilliefors test. Through analysis of variance, the significant effects of the application rates, cultivars, and application rate $x$ cultivar interaction were notable (Table 1). From the results, analyses were deployed to allow us to examine the development of the various characteristics of seedlings and plants.

The bioassay efficiency for identifying soybean seeds as herbicide-tolerant or herbicide-sensitive was confirmed by the germination test in moistened paper with glyphosate solutions. The tolerant genotypes Agua Marinha RR, Citrino RR, Opala RR, and Turqueza RR showed reduction in the percentage of normal seedlings only when treated with the $0.12 \%$ solution (Table 2 ), whereas for the sensitive genotype (UFV16), all treatments with the herbicide inhibited the development of normal seedlings at five and eight days (Cunha et al. 2005, Pereira et al. 2009a, Bervald et al. 2010). Although the seedlings emit their primary roots, they have no secondary roots (Cunha et al. 2005).

Table 1. Summary of analysis of variance in regard to physiological quality (FC5: Percentage of normal seedlings in the first count of germination, transformed into arc sin; FC8: Percentage of normal seedlings in the final count of germination, transformed into Arcsen), seedling length (HL: Hypocotyl Length; RL: Radicle Length; SL: Seedling Length), and plant cycle (PH: Plant Height; HP: Height of First Pod; DWS: Dry Weight of Stem; DMS: Diameter of Main Stem; DWP: Dry Weight of Pods; NB: Number of Branches in Main Stem; NP: Number of Pods; NSP: Number of Seeds per Pod; TNS: Total Number of Seeds; YP: Yield per Plant)

\begin{tabular}{|c|c|c|c|c|c|c|c|c|c|c|c|}
\hline sv & df & \multicolumn{3}{|c|}{$\begin{array}{c}\text { MS } \\
\text { Physiological Quality }\end{array}$} & & SV & df & \multicolumn{4}{|c|}{$\begin{array}{c}\text { MS } \\
\text { Seedling Length }\end{array}$} \\
\hline$A R$ & 3 & $0.304^{*}$ & \multicolumn{2}{|c|}{$0.198^{*}$} & & $A R$ & 3 & $129.4^{*}$ & \multicolumn{2}{|c|}{$2064^{*}$} & 3188* \\
\hline$A R \times C$ & 15 & $0.104^{*}$ & \multicolumn{2}{|c|}{$0.116^{*}$} & & $A R \times C$ & 15 & $2.406^{*}$ & \multicolumn{2}{|c|}{$6.571^{*}$} & $8.828^{*}$ \\
\hline Error & 72 & 0.001 & \multicolumn{2}{|c|}{0.0005} & & Error & 168 & 0.449 & \multicolumn{2}{|c|}{0.788} & 1.659 \\
\hline Mean & & \multicolumn{10}{|c|}{$\begin{array}{c}\text { MS } \\
\text { Plant Cycle }\end{array}$} \\
\hline sV & df & PH & HP & DWS & DMS & DWP & NB & NP & NSP & SN & YP \\
\hline$A R$ & 3 & $2507^{*}$ & $117.2^{*}$ & 93.37* & $8.56^{*}$ & $36.42 *$ & $38.40 *$ & $2392^{*}$ & $0.128^{*}$ & $8632 *$ & $258.6^{*}$ \\
\hline C & 5 & $5287^{*}$ & $324.3^{*}$ & 429.9* & $48.3^{*}$ & $74.92 *$ & $46.89 *$ & 7769* & $0.821^{*}$ & $25218^{*}$ & $595.7^{*}$ \\
\hline Mean & & 71.72 & 15.41 & 19.81 & 7.859 & 11.55 & 7.405 & 77.08 & 2.051 & 159.9 & 22.87 \\
\hline
\end{tabular}

AR: Herbicide application rates; C: Cultivars; AR x C: Interaction between factors. ${ }^{*}$ Significant at $5 \%$ probability by the F test. 
Table 2. Adjusted percentage of normal seedlings at the first count and final count of germination, depending on the application rate of the herbicide solution $(0,0.03,0.06$, and $0.12 \%)$ in the germination test, of six soybean cultivars: UFVS Agua Marinha RR (CV1), UFVS Berilo RR (CV2), UFVS Citrino RR (CV3), UFVS Opala RR (CV4), UFVS Turqueza RR (CV5), and UFV-16 (CV6). The data were plotted in comparison to the control group (application rate 0 ), set at $100 \%$, with the remaining weighted sequence

\begin{tabular}{|c|c|c|c|c|c|c|}
\hline \multirow[b]{2}{*}{ Application rate } & \multicolumn{6}{|c|}{ First count of germination (FC5) } \\
\hline & CV1 & CV2 & CV3 & CV4 & CV5 & CV6 \\
\hline 0 & $100 \mathrm{a}$ & $100 \mathrm{a}$ & $100 \mathrm{a}$ & $100 \mathrm{a}$ & $100 \mathrm{a}$ & $100 \mathrm{a}$ \\
\hline 0.03 & $94.8 \mathrm{a}$ & $94.1 \mathrm{a}$ & $95.6 \mathrm{a}$ & 95.9 a & $99.2 \mathrm{a}$ & $\mathrm{ob}$ \\
\hline 0.06 & $95.8 \mathrm{a}$ & $94.1 \mathrm{a}$ & $91.7 \mathrm{a}$ & $95.4 \mathrm{a}$ & $97.3 \mathrm{a}$ & $0 \mathrm{~b}$ \\
\hline \multirow[t]{2}{*}{0.12} & $81.6 \mathrm{~b}$ & $93.2 \mathrm{a}$ & $77.5 \mathrm{~b}$ & $81.6 \mathrm{~b}$ & $84.7 \mathrm{~b}$ & $0 \mathrm{~b}$ \\
\hline & \multicolumn{6}{|c|}{ Final count of the germination (FC8) } \\
\hline 0.06 & $98.6 \mathrm{a}$ & $97.1 \mathrm{a}$ & $92.8 \mathrm{~b}$ & $98.6 \mathrm{a}$ & $96.1 \mathrm{a}$ & $0 \mathrm{~b}$ \\
\hline 0.12 & $86.9 \mathrm{c}$ & $97.4 \mathrm{a}$ & $88.7 \mathrm{~b}$ & $94.8 \mathrm{a}$ & 96.6 a & $0 \mathrm{~b}$ \\
\hline
\end{tabular}

Within each genotype (column), means followed by the same letter do not differ by the Scott-Knott test at $5 \%$ probability

The function of EPSP synthase is to catalyze the transfer of the enolpyruvyl moiety of phosphoenolpyruvate (PEP) to the 5-hydroxyl of shikimate-3-phosphate (S3P). As glyphosate and PEP share the same binding site in the enzyme, the presence of this herbicide inhibits the enzyme action in the plant. RR cultivars overcome this inhibition by the presence of CP4 EPSPS, characterized by their reduced affinity to glyphosate (Funke et al. 2006).

As the tests were conducted, reduction in the length of seedlings due to an increase in herbicide concentration was notable, especially for tolerant cultivars. When glyphosate concentration increases, physiological quality and vigor decline, even in herbicide-tolerant cultivars (Albrecht et al. 2014). To confirm this reduction, the seedling length test was conducted (Pereira et al. 2009b). There was reduction in hypocotyl, radicle (Zonetti et al. 2011), and seedling lengths for all cultivars with the herbicide treatments compared to the control group, especially for individuals with stalled development.

Undoubtedly, total length was a crucial feature for characterization of sensitive seedlings (Figure 1). For the sensitive cultivar (UFV16), the small length and lack of secondary roots characterize the halt in seedling development (Cunha et al. 2005). Although all cultivars showed reduction in this feature due to the increase in herbicide application rate, the greatest impact was evident in the sensitive seedlings (Albrecht et al. 2014). Therefore, along with the lack of secondary roots, sudden reduction in seedling length confirmed identification of herbicide-sensitive seedlings in the germination test, as Cunha et al. (2005), Pereira et al. (2009a), and Bervald et al. (2010) also verified. In regard to application rates, the $0.06 \%$ rate is the most suitable for investigating herbicide tolerance or sensitivity. Rates above or below this concentration may result in false-positives and false-negatives, respectively (Pereira et al. 2009a).

In view of the findings, the main question of this article was whether the seedlings subjected to this bioassay, mainly herbicide-sensitive seedlings with reduction in overall length and lack of secondary roots, would be able to recover their development along the plant cycle when transplanted into soil without herbicide. To verify viability, samples of 10 seedlings per experimental plot, obtained from the germination test, were transplanted to pots containing properly screened and fertilized soil. Fertilization was carried out at sowing and in topdressing 35 days after sowing. In fertilization at sowing, the equivalent of $20 \mathrm{~kg} \mathrm{ha}^{-1}$ of $\mathrm{N}, 120 \mathrm{~kg} \mathrm{ha}^{-1}$ of $\mathrm{P}_{2} \mathrm{O}_{5}$, and $80 \mathrm{~kg} \mathrm{ha}^{-1}$ of $\mathrm{K}_{2} \mathrm{O}$ were applied, and in topdressed fertilization, $50 \mathrm{~kg} \mathrm{ha}^{-1}$ of $\mathrm{K}_{2} \mathrm{O}$.

In the case of UFV-16, abnormal seedlings, due to the absence of secondary roots and whose development was halted, were selected and transplanted to verify their capacity for recovering development under greenhouse conditions. These pots were randomized in the greenhouse and maintained throughout the crop cycle, which began in the first half of November and finished in May. The temperature during the cycle ranged from $20.4^{\circ} \mathrm{C}$ (minimum) to $40.6^{\circ} \mathrm{C}$ (maximum).

Overall, the recovery of the tolerant plants was remarkable. For sensitive plants, recovery was less pronounced, but occurred. Matsuo et al. (2009) also reported a certain recovery of strains sensitive to the herbicide. As for tolerant cultivars, the accumulation of biomass in tissues of agronomic interest may be affected as a function of herbicide 

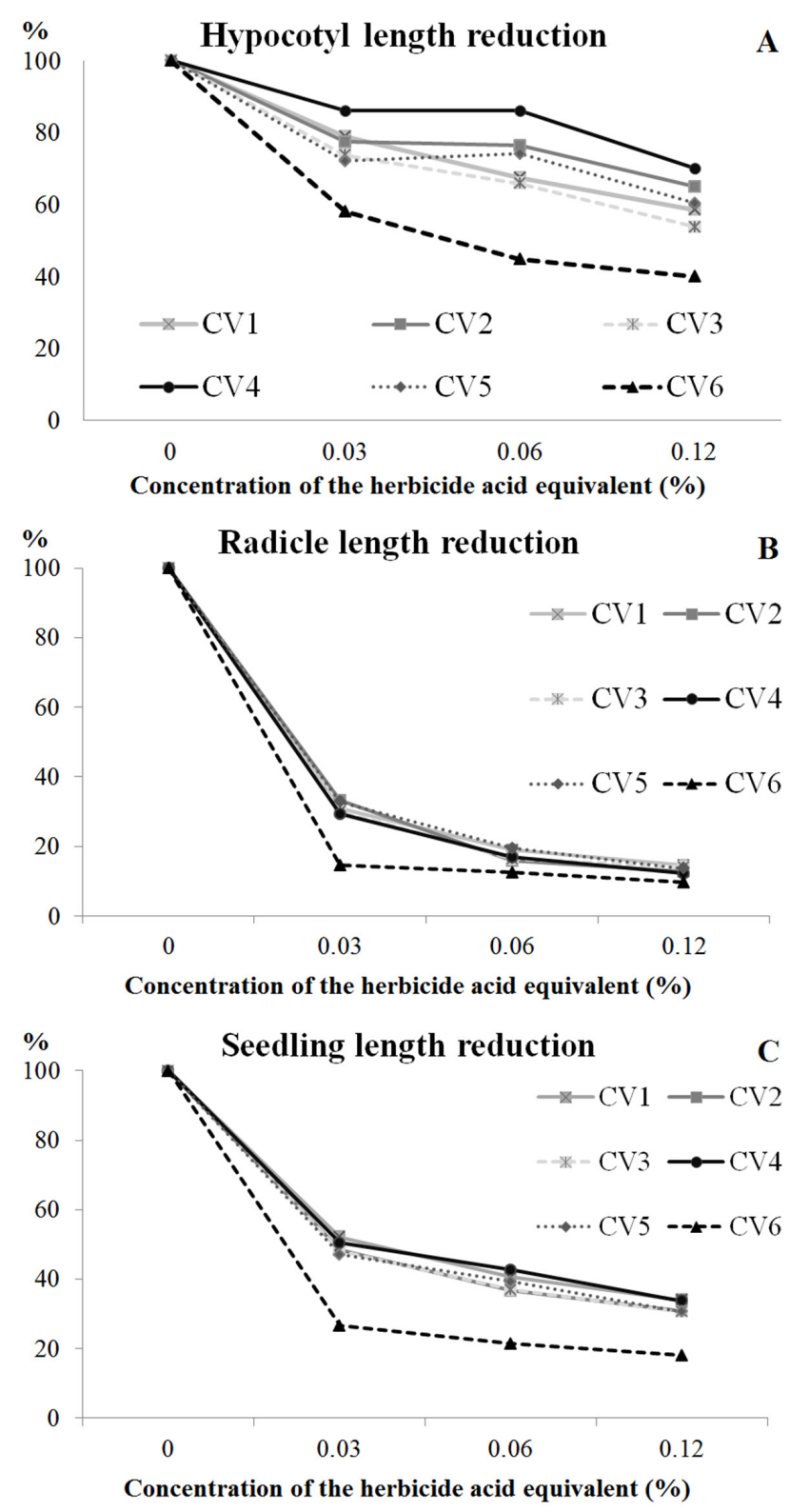

Figure 1. Reduction in the hypocotyl (A), radicle (B), and seedling (C) length due to concentration of herbicide acid equivalent of $0,0.03,0.06$, and $0.12 \%$. The data are presented according to the control treatment (application rate 0), set at 100\%. From this, other data were corrected for each genotype: UFVS Agua Marinha RR (CV1), UFVS Berilo RR (CV2), UFVS Citrino RR (CV3), UFVS Opala RR (CV4), UFVS Turqueza RR (CV5), and UFV-16 (CV6). application rate and time of application, with potential negative effects on vegetative, productive, and seed quality (Albrecht et al. 2014). In our study, the highest herbicide concentration used in the germination test $(0.12 \%)$ impaired the performance of tolerant cultivars only at the level of seedling emergence.

The first notable characteristic was plant height at the end of the cycle. Among cultivars tolerant to the herbicide, only Berilo RR seedlings showed a subtle decrease in length when treated with glyphosate (Figure 2A). The other tolerant cultivars had plants with a length similar to control group plants, as observed by Procópio et al. (2007). In the case of plants from the sensitive cultivar, there was reduction in the average plant height at concentrations of $0.06 \%$ and $0.12 \%$ of the herbicide used in this study, and plants did not exceed $33 \mathrm{~cm}$.

A direct implication of reduction in plant height is reduction in the first pod height (Figure $2 \mathrm{~B}$ ). For this feature, no effect was found among cultivars tolerant to the herbicide, whereas for the sensitive cultivar, the reduction in first pod height was significant in the treatments of 0.06 and $0.12 \%$ herbicide.

Among other findings obtained in this study about the plant architecture, the diameter of the main stem (Figure 2C) showed reduction only at the highest concentration of herbicide. Other characteristics, such as dry weight of stems (Figure 3D), number of branches in the main stem (Figure $3 \mathrm{E}$ ), and dry weight of pods (Figure 3F) decreased at the application rates of $0.06 \%$ and $0.12 \%$ of the herbicide. In the case of plants tolerant to glyphosate, in general, there were no negative effects, as also reported by Kruse et al. (2000), Matsuo et al. (2009), and Correia and Durigan (2007). All these vegetative characteristics together showed that recovery of tolerant plants is satisfactory, but in the case of sensitive cultivars, there are persistent losses in the plant cycle due to the herbicide rate used in the germination bioassay (Albrecht et al. 2014).

In regard to production components, the effects followed the trend of those previously observed for the characteristics of vegetative development. Number of pods on the plant (Figure $3 A$ ), number of seeds per pod (Figure 3B), total number of seeds (Figure $3 C$ ), and yield per plant (Figure $3 \mathrm{D}$ ) were reduced at the concentrations of 0.06 and $0.12 \%$ of the herbicide only in plants of the sensitive cultivar.

An assay performed by Gris et al. (2013) showed that herbicide application on herbicide-tolerant plants under either field or greenhouse conditions, which would be more stressful conditions than germination in a moistened substrate with glyphosate, did not change seed physiological quality, confirming the result of plant recovery in this study. Matsuo et al. (2009) did not observe symptoms from herbicide in tolerant plants after they were sprayed with glyphosate under 
greenhouse conditions. Herbicide-tolerant plants were able to overcome leaf application of the herbicide at commercial application rates due to the activity of the CP4 EPSPs enzyme (Padgette et al. 1995), whose catalytic capacity remained essentially unchanged even in the presence of glyphosate (Funke et al. 2006), giving the plant the ability to synthesize aromatic amino acids (Kruse et al. 2000).

In general, non-RR plants showed developmental delay when in contact with glyphosate, which may have affected both their development and production. Genotypes that do not have the genetically modified characteristic quickly suffer the effects of glyphosate, showing high toxicity even at low rates of the herbicide (Matsuo et al. 2009). Similarly, a study with coffee powdered with glyphosate showed reduction in water use efficiency, which can result in stunted growth and reduced production by cultivars less tolerant to the herbicide (Carvalho et al. 2014).

De Vries and Fehr (2011), in their study of hybridization between cultivars tolerant and sensitive to glyphosate (MON89788 event), showed the possibility of obtaining sensitive and tolerant lines by backcrossing similar in terms of plant architecture, yield, and composition of seeds. The screening method was adopted for spraying plants and eliminating
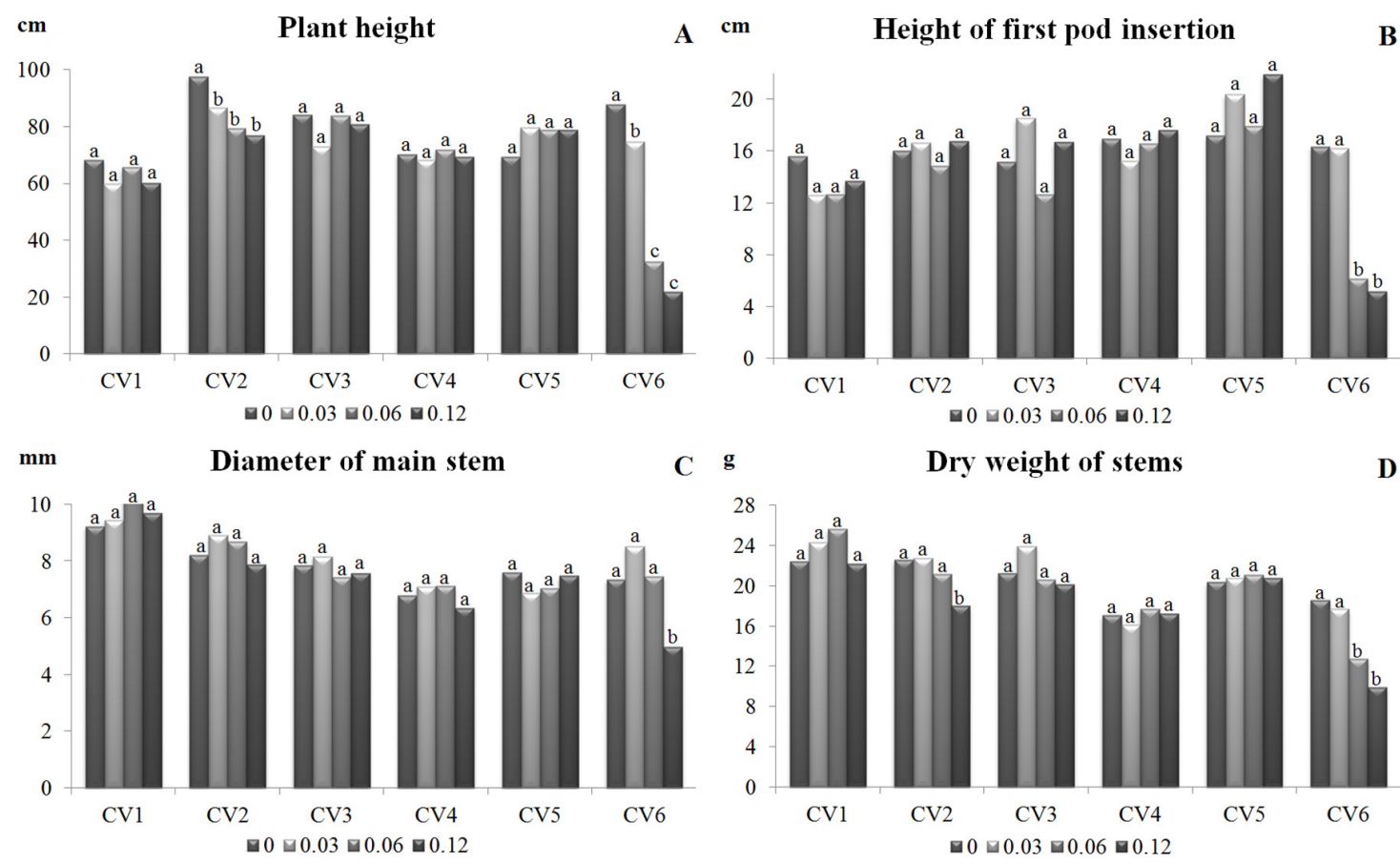

C $\mathbf{g}$

Dry weight of stems

D
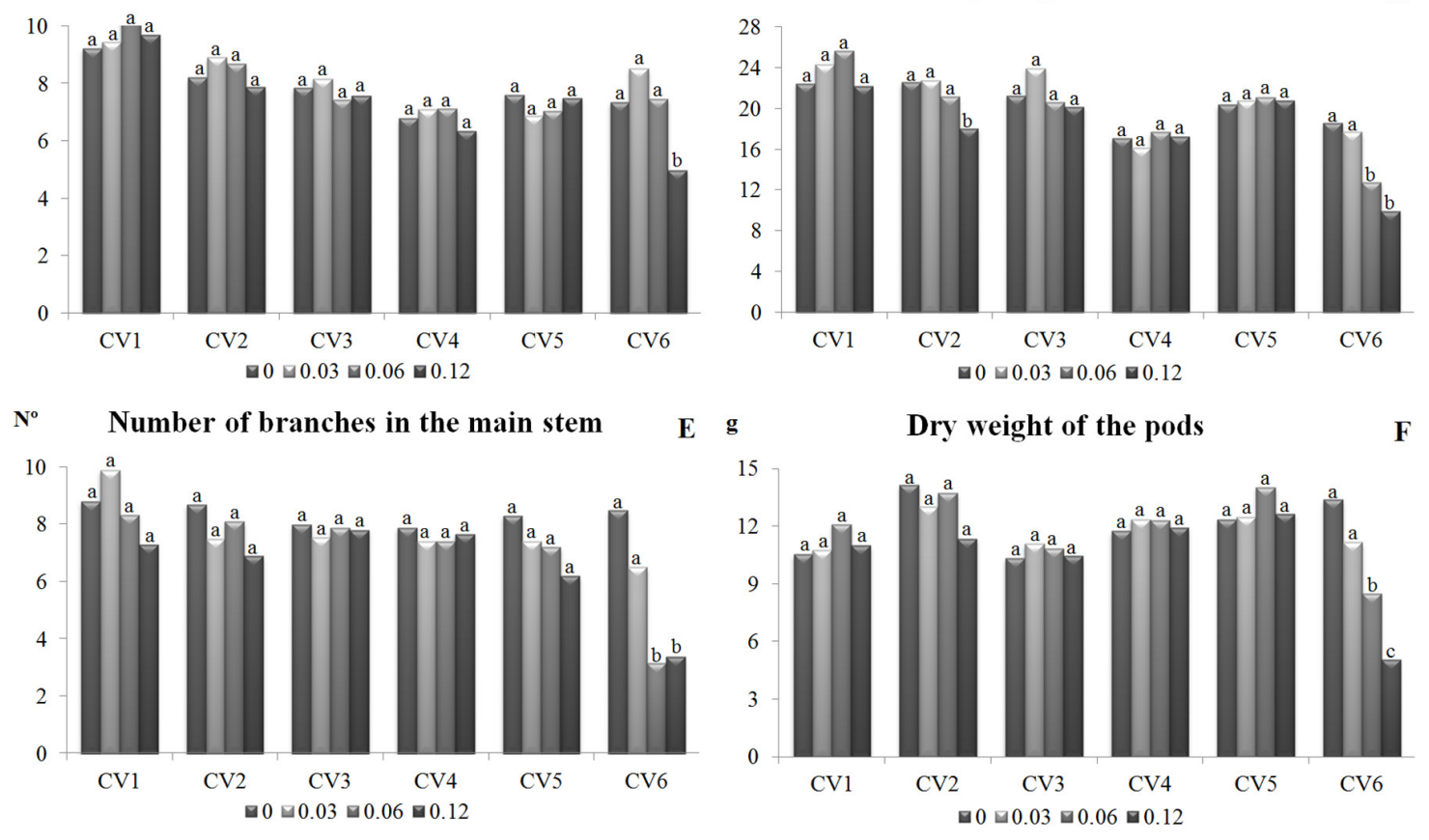

Figure 2. Plant height $(A)$ and height of first pod (B) in centimeters, diameter of main stem in millimeters (C), dry weight of the pods in grams (D), number of branches in the main stem (E), and dry weight of the pods in grams (F) of cultivars UFVS Agua Marinha RR (CV1), UFVS Berilo RR (CV2), UFVS Citrino RR (CV3), UFVS Opala RR (CV4), UFVS Turqueza RR (CV5), and UFV-16 (CV6). Within each genotype, columns followed by the same letter do not differ by the Scott-Knott test at $5 \%$ probability. 
herbicide-sensitive individuals. Of course, continuing with sensitive plants after herbicide application was impossible because they died. However, with herbicide-tolerant plants, under greenhouse or field conditions, spraying plants with glyphosate did not alter the physiological quality of seeds and the lignin contents in the plant (Gris et al. 2013).

In the case of plant breeding, the possibility of obtaining the seeds from the plant itself that was phenotypically evaluated for herbicide tolerance is an interesting approach in regard to time saved in advancing the segregating populations, and in regard to the cost-benefit ratio.

In our study, we showed that using the germination test in a moistened substrate with glyphosate, it is possible to continue the plant cycle, even when the plant is sensitive to the herbicide. This is because seedlings with development halted in post-germination stages can recover when the glyphosate has been removed from their environment. We suggest adopting the germination test in moistened paper with $0.06 \%$ glyphosate as a method for initial screening of seeds (Pereira et al. 2009a), and, subsequently, samples may be obtained for molecular confirmation by PCR. Undoubtedly, this routine can significantly reduce costs for certification of tolerance or sensitivity to the herbicide due to the transgenic event.

Padgette et al. (1995) selected individual RR families after spraying with herbicide under greenhouse conditions. At that time, the researchers scored the R1 families for herbicide-tolerance on a scale of 0 (completely dead) to 10 (similar to unsprayed control plants within the same progeny). Evaluations were performed at 7, 14, and 28 days after spraying. Segregation was performed only for tolerant plants, since sensitive individuals had extensive chlorosis, senescence, and death.

From our study, we suggest a methodology based on the germination test on a moistened substrate with $0.06 \%$ glyphosate solution, which has some practical advantages for breeding programs: i) The germination test is finished in 7 days, which means time savings; ii) the environment of the experiment is controlled for both temperature $\left(25^{\circ} \mathrm{C}\right)$ and humidity (95\%); iii) the space required is minimal, considering that 50 seeds are arranged in only one roll of filter paper; iv) the material consumed consists of germination paper, water, and glyphosate, whereas in the greenhouse, the test
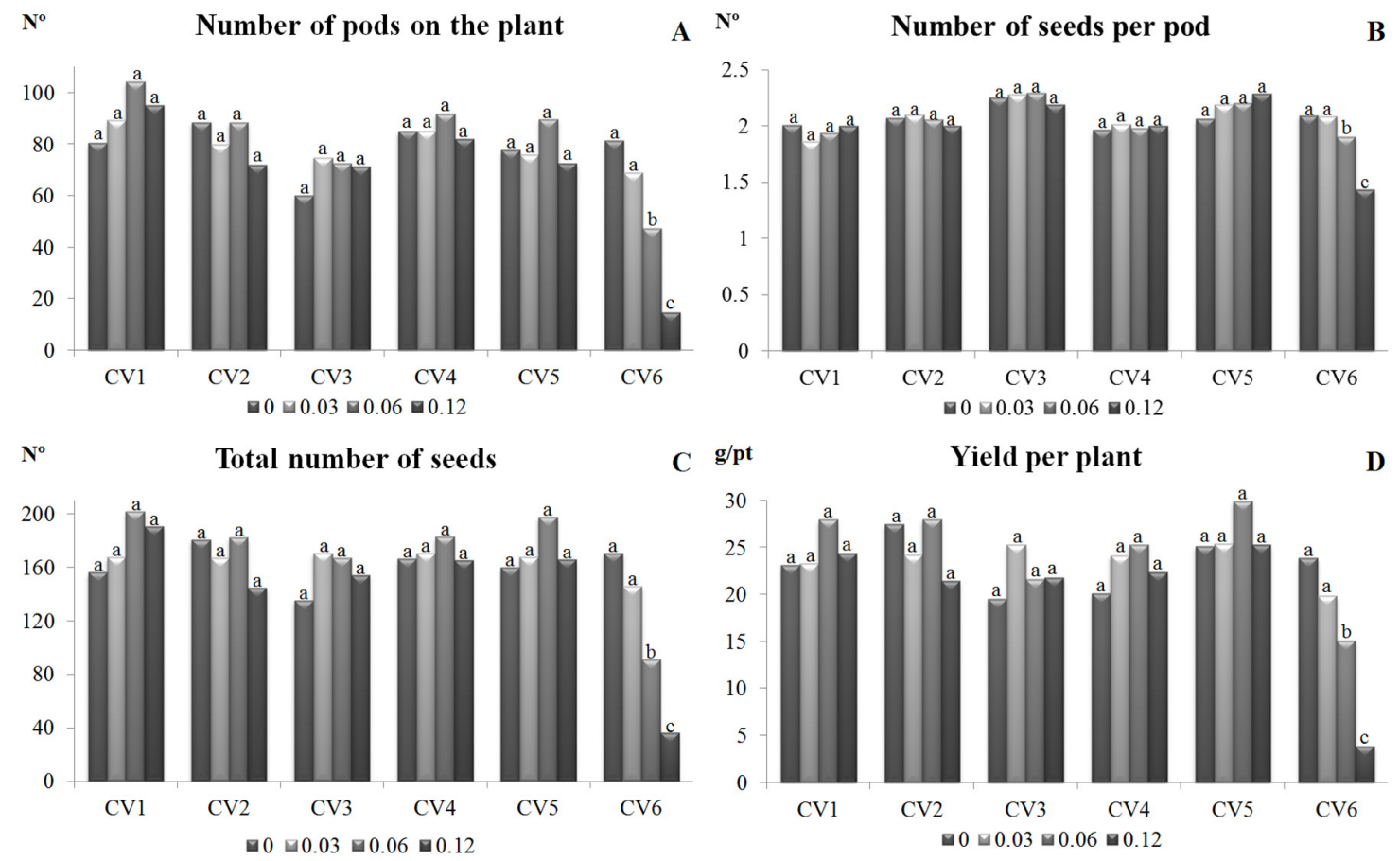

C $\mathrm{g} / \mathrm{pt}$

Yield per plant

D

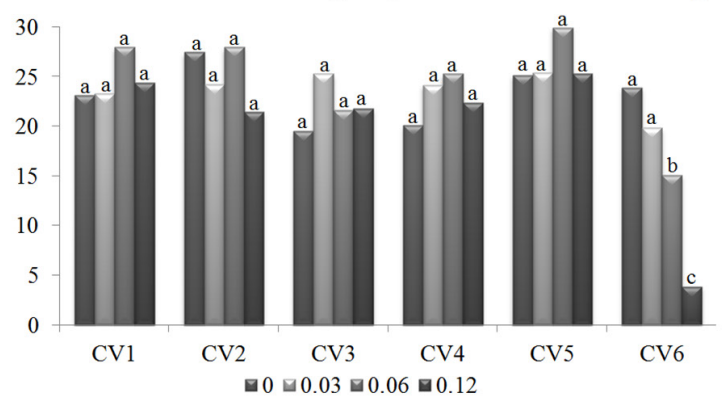

Figure 3. Number of pods on the plant (A), number of seeds per pod (B), total number of seeds (C), and yield per plant (D) of cultivars UFVS Agua Marinha RR (CV1), UFVS Berilo RR (CV2), UFVS Citrino RR (CV3), UFVS Opala RR (CV4), UFVS Turqueza RR (CV5), and UFV-16 (CV6). Within each genotype, columns followed by the same letter do not differ by the Scott-Knott test at $5 \%$ probability. 
would require pots and substrate; v) the amount of herbicide applied in the paper moistening solution is significantly lower than that used in greenhouse spraying; vi) the germination test is significantly more practical than the handling of a sprayer; and vii) sensitive individuals have the capacity to recover development after being transferred to the soil.

\section{REFERENCES}

Albrecht LP, Albrecht AJP, Braccini AL, Oliveira Jr RS, Zobiole LHS and Ávila MR (2014) The role of glyphosate in RR soybean production and seed quality. Planta daninha 32: 401-407.

Bervald CMP, Mendes CR, Timm FC, Moraes DM, Barros ACSA and Peske ST (2010) Desempenho fisiológico de sementes de soja de cultivares convencional e transgênica submetidas ao glifosato. Revista Brasileira de Sementes 32: 9-18.

Brasil (2009) Regras para análise de sementes. Ministério da Agricultura, Pecuária e Abastecimento, Secretaria de Defesa Agropecuária, Brasília, 399p.

Carvalho FP, França AC, Souza BP, Fialho CMT, Santos JB and Silva AA (2014) Water use efficiency by coffee arabica after glyphosate application. Acta Scientiarum. Agronomy 36: 373-377.

Conceição FR, Moreira AN and Binsfeld PC (2006) Detecção e quantificação de organismos geneticamente modificados em alimentos e ingredientes alimentares. Ciência Rural 36: 315-324.

Correia NM and Durigan JC (2007) Seletividade de diferentes herbicidas à base de glyphosate à soja RR. Planta Daninha 25: 375-379.

Cruz CD (2013) GENES - a software package for analysis in experimental statistics and quantitative genetics Acta Scientiarum. Agronomy 35: 271-276.

Cunha CSM, Tillmann MAA, Villela FA, Dode LB and Balerini F (2005) Comparação de métodos na detecção de sementes de soja geneticamente modificada resistente ao glifosato. Revista Brasileira de Sementes 27: 167-175

De Vries BD and Fehr WR (2011) Impact of the MON89788 event for glyphosate tolerance on agronomic and seed traits of soybean. Crop Science 51: 1023-1027.

Fraiture MA, Herman P, Taverniers I, Loose MD, Deforce D and Roosens $\mathrm{NH}$ (2015) Current and new approaches in GMO detection: challenges and solutions. BioMed Research International 2015: 1-22.

Funke T, Han H, Healy-Fried ML, Fischer M and Schönbrunn E (2006) Molecular basis for the herbicide resistance of Roundup Ready crops. Proceedings of the National Academy of Sciences 103: 13010-13015.

Gris CF, Von Pinho EVR, Carvalho MLM, Diniz RP and Andrade T (2013) Lignificação da planta e qualidade de sementes de soja RR pulverizadas com herbicida glifosato. Revista Ceres 60: 286-292.

James C (2014) Global status of commercialized biotech/GM crops: 2014. ISAAA, Ithaca, 270p. (ISAAA Brief No. 49).

Klümper W and Qaim M (2014) A meta-analysis of the impacts of genetically modified crops. Plos One 9: 1-7.

Kruse ND, Trezzi MM and Vidal RA (2000) Herbicidas inibidores da EPSPS: revisão de literatura. Revista Brasileira de Herbicidas 1: 139-146.

Matsuo E, Sediyama T, Cruz CD, Silva AA, Oliveira RCT, Nogueira APO and Tancredi FD (2009) Resistência de genótipos de soja ao herbicida glyphosate. Planta Daninha 27: 1063-1073.

Miranda DM, Tillmann MAA, Noldin JA and Balerini F (2006) Bioensaio em casa-de-vegetação na detecção e quantificação de sementes de soja geneticamente modificada. Revista Brasileira de Sementes 28: 187-192.

Nepomuceno M, Alves PLCA, Dias TCS and Pavani MCMD (2007) Períodos de interferência das plantas daninhas na cultura da soja nos sistemas de semeadura direta e convencional. Planta Daninha 25: 43-50.

Padgette R, Kolacz KH, Delannay X, Re DB, Lavallee BJ, Tinius CN, Rhodes WK, Otero I, Barry GF and Kishore GM (1995) Development, identification and characterization of a glyphosate-tolerant soybean line. Crop Science 25: 1451-1461.

Pereira WA, Lisboa SP, Dias DCFS, Alvarenga EM and Borém A (2009a) Ajuste de metodologias para a identificação de cultivares de soja quanto à tolerância ao glifosato, Revista Brasileira de Sementes 31: 133-144.

Pereira WA, Sávio FL, Borém A and Dias DCFS (2009b) Influência da disposição, número e tamanho das sementes no teste de comprimento de plântulas de soja. Revista Brasileira de Sementes 31: 113-121.

Pittelkow FK, Jakelaitis A, Conus LA, Oliveira AA, Gil JO, Assis FC and Borchartt L (2009) Interferência de plantas daninhas na cultura da soja transgênica. Global Science and Technology 2: 38-48.

Procópio SO, Menezes CCE, Betta L and Betta M (2007) Utilização de chlorimuron-ethyl e imazethapyr na cultura da soja Roundup Ready". Planta daninha 25: 365-373.

Zonetti PC, Suzuki LS, Bonini EA, Ferrarese MLL and Ferrarese-Filho O (2011) Growth and root lignification of susceptible and glyphosateresistant soybean Acta Scientiarum. Agronomy 33: 291-295.

(cc) EY This is an Open Access article distributed under the terms of the Creative Commons Attribution License, which permits unrestricted use, distribution, and reproduction in any medium, provided the original work is properly cited. 